\title{
Motorcycle Accidents: Morbidity and Associated Factors in a city of Northeast of Brazil
}

\author{
ALESSANDRO L. CAVALCANTI', BELCHIOR M. LUCENA', IRIS S.A. RODRIGUES ${ }^{1}$, AMANDA L. SILVA', TAUA T. \\ LIMA ${ }^{2}$ and ALIDIANNE F. C. XAVIER \\ ${ }^{1}$ State University of Paraiba, Campina Grande, PB, Brazil \\ ${ }^{2}$ Federal University of Campina Grande, Campina Grande, PB, Brazil
}

\begin{abstract}
Motorcycle accidents are becoming a public health problem in developing world. The objective of this paper was to assess the factors related to morbidity and mortality among victims of motorcycle accidents in a trauma center. An analysis of 9,734 medical records of patients hospitalized for external causes at the Regional Emergency and Trauma Hospital of Campina Grande, Paraiba, Brazil, from January to December 2009 was done. The cases of accidents with motorcycles accounted for $20.8 \%$ of all hospital care, mostly affecting men (85.8\%) aged $21-29$ years old (33.9\%). Legs and feet (55.2\%) and arms and hands (26.9\%) were the most affected parts of the body. The association between the occurrence of motorcycle accident affecting the face $(p=0.001)$, the chest $(p<0.001)$, arms and hands $(p=0.004)$ and legs and feet $(p<0.001)$ was observed. Multiple lesions were present in $40.4 \%$ of the cases; and the majority ( $80.6 \%$ ) involved fractures. Amputation and functional impairment were observed in $15.3 \%$ and $4.3 \%$ of the victims, respectively. Vascular lesions in the lower limbs had a 3.5 times higher chance of occurrence among injured motorcyclists. Fatal accidents accounted for $1.3 \%$ of the injured victims. In conclusion, motorcycle accidents affect men, predominantly, most of them being young, causing fractures and multiple lesions, mainly in the lower limbs. There is need for greater incentive to actions concerning traffic safety education focusing on motorcyclists, as well as greater control by competent authorities as regards to the use of motorcycles in the country.
\end{abstract}

Keywords: accidents, traffic, morbidity, mortality, motorcycles, Brazil

\section{Introduction}

In recent years, there has been a growing concern with the significant increase of individuals injured as a result of accidents involving motorcycles in a number of countries (Naci et al., 2009) Despite the use of motorcycles as a major means of transport in some countries (Fitzharris et al., 2009; Haquea et al., 2009; Oluwadiyaa et al., 2009), or even as an instrument of leisure in others (Bevan et al., 2008; Jamaa et al., 2011; Mikocka-Walus et al., 2010; Weiss et al., 2010), these vehicles constitute a means of transport considered very risky (Nunn, 2011). This is because they do not have safety devices to the entire body or protection structure for drivers and passengers (Albalate \& Fernàndez-Villadangos, 2010). In this context, motorcyclists are considered one of the groups most vulnerable to transport accidents (Peden et al., 2004; WHO, 2009). In Brazil, motorcycles are the second largest fleet of vehicles; but they are responsible for the highest death rate due to traffic accidents. In Singapore, motorcycles constitute about $19 \%$ of all vehicles; yet they are responsible for only $36 \%$ of total accidents (Haquea et al., 2008). In Great Britain, motorcycles account for less than $1 \%$ of vehicles, but drivers suffer $14 \%$ of total deaths and serious injuries in roads (Clarke et al., 2007).

In Brazil, most of the population makes use of motorcycles to move around. Motorcycles are also used as a work vehicle for taxi motorcyclists and delivery men. Moreover, this means of transport has lower cost compared to others and is accessible to low-income people who use it as locomotion vehicle (Cavalcanti et al., 2011). Considering that motorcycle accidents are a major cause of injuries related with fatalities and disabling injuries (MacLeod et al., 2010), several studies have attempted to identify how individual (sex, age, licensing), behavioral (over-speed, alcohol use), geophysical (structure of roads) and situational factors (impact objects) may be linked to the greater involvement of motorcyclists in traffic accidents (Nunn, 2011; Savolainen \& Mannering, 2007; Haquea et al., 2008; Oluwadiyaa et al., 2009; Albalate \& Fernàndez-Villadangos, 2010).

Given the importance of understanding the magnitude of road accidents for the implementation of public policies, the objective of this study was to evaluate the factors associated with morbidity and mortality among victims of motorcycle accidents at a trauma 
center in a city in north-eastern Brazil. In order to understand the magnitude of accidents involving motorcyclists, the Trauma and Emergency Hospital of Campina Grande was selected for the conduction of this study. This choice was due to the fact that this institution represents the only public health service with high complexity, which is reference for the treatment of patients affected by external causes in the semiarid region of the state of Paraiba.

\section{Materials and Methods}

\section{Study area and medical record review}

This study was conducted in Campina Grande, which is the second most important city in the state of Paraiba, Brazil. The city is about $130 \mathrm{~km}$ from the capital of Paraiba State and is located in the "Agreste" region in the eastern region of the Borborema plateau. The city has an estimated population of 371,060 habitants and a municipal human development index (HDI) value of 0.72 .

The study sample included an analysis of 9,734 medical records. The sample consisted of all medical records of children and adults affected by motorcycle accidents, duly verified and hospitalized due to injuries at the Regional Emergency and Trauma Hospital of Campina Grande, Paraiba, from January to December 2009.

The following variables were analyzed: age group, sex, date of the accident, the injured region of the body (head, face, thorax, arms and hands, legs and feet), number of injuries (single and multiple), presence of vascular lesion, number of surgical interventions, presence of fracture, functional impairment, limb amputation and death.

\section{Data analysis}

Data analysis involved descriptive statistics (frequency distribution) and analytic statistics. For inferential analyses, Odds Ratio was used as a measure of association. Pearson's chi-square was used to test for statistical differences between comparisons groups with significance level set at 95\%. The statistical programme used was SPSS (Statistical Package for Social Sciences) version 15.

\section{Ethical considerations}

This study was conducted in compliance with the ethical guidelines issued by the Resolution 196/96 of the Brazilian National Health Council/Ministry of Health on research involving human subjects. The research project was independently reviewed and approved by the Ethics in Research Committee of the State University of Paraiba, Brazil.

\section{Results}

Cases of motorcycle accidents accounted for $20.8 \%(n=372)$ of hospitalizations due to external causes, and 319 victims, (85.8\%) were men with a sex ratio of 6.0:1. Men were two times more likely to suffer motorcycle accident compared to women. Majority of victims were in the age group 21-29 years old (33.9\%) with $41.9 \%$ of cases reported to have occurred over the weekend days (Saturday and Sunday). The percentages of motorcycle accidents were higher in the following age groups: $21-29$ years (33.9\%), 30 to 39 years (28.3\%) and $40-49(22.2 \%)$ and the lowest in the age group 0- 9 years (0.9\%) and 60 or older (9.5\%) (Table 1$)$.

When analyzing body part that was injured, legs and feet $(55.2 \%)$ and arms and hands (26.9\%) were the most affected regions and victims of motorcycle accidents were 2.59 times more likely to suffer injuries on legs and feet. There was association between the occurrence of motorcycle accidents with injuries on face $(p=0.001)$, thorax $(p<0.001)$, arms and hands $(p=$ $0.004)$, legs and feet ( $p$ <.001). The percentage of victims who had lesions on face $(17.4 \%$ versus $10.9 \%$ ) and legs and feet (55.2\% versus $32.2 \%$ ) were higher among those who have suffered motorcycle accidents (Table 2 ). 
Table 1: Occurrence of motorcycle accidents by age, sex and day of the week

\begin{tabular}{|c|c|c|c|c|c|c|c|c|}
\hline \multirow[t]{3}{*}{ Variable } & & \multicolumn{5}{|c|}{ Motorcycle accidents } & \multirow[t]{3}{*}{ P-value } & \multirow[t]{3}{*}{ OR (IC95\%) } \\
\hline & & \multicolumn{2}{|c|}{ Yes } & \multicolumn{2}{|l|}{ No } & \multirow{2}{*}{$\begin{array}{l}\text { Total } \\
\mathrm{N}\end{array}$} & & \\
\hline & & $\mathrm{N}$ & $\%$ & $\mathrm{~N}$ & $\%$ & & & \\
\hline \multirow[t]{8}{*}{ Age group } & $0-9$ & 2 & 0.9 & 216 & 99.1 & 218 & $<0.001$ & - \\
\hline & $10-20$ & 53 & 16.1 & 277 & 83.9 & 330 & & - \\
\hline & $21-29$ & 151 & 33.9 & 295 & 66.1 & 446 & & - \\
\hline & $30-39$ & 86 & 28.3 & 218 & 71.7 & 304 & & - \\
\hline & $40-49$ & 40 & 22.2 & 140 & 77.8 & 180 & & - \\
\hline & $50-59$ & 18 & 16.5 & 91 & 83.5 & 109 & & - \\
\hline & $\geq 60$ & 18 & $9 \cdot 5$ & 172 & 90.5 & 190 & & - \\
\hline & Total† & 368 & 20.7 & 1409 & $79 \cdot 3$ & 1777 & & - \\
\hline \multirow[t]{3}{*}{ Sex } & Male & 319 & 232 & 1057 & 76.8 & 1376 & $<0.001$ & $2.05(1.50-2.81)$ \\
\hline & Female & 53 & 12.8 & 360 & 87.2 & 413 & & 1.00 \\
\hline & Total & 372 & 20.8 & 1417 & 79.2 & 1789 & & \\
\hline \multirow[t]{3}{*}{ Day } & Weekends & 156 & 26.7 & 428 & $73 \cdot 3$ & 584 & $<0.001$ & $1.67(1.32-2.11)$ \\
\hline & Weekdays & 216 & 17.9 & 989 & 82.1 & 1205 & & 1.00 \\
\hline & Total & 372 & 20.8 & 1417 & 79.2 & 1789 & & \\
\hline
\end{tabular}

Key: $\uparrow$ - Information was missing in four medical records; Weekends= Saturday and Sunday; Weekdays= Monday-Friday

Table 2: Association between body part that was injured and the occurrence of motorcycle accidents

\begin{tabular}{|c|c|c|c|c|c|c|c|c|c|}
\hline \multirow{3}{*}{ Body part } & & \multicolumn{6}{|c|}{ Motorcycle accidents } & \multirow[t]{3}{*}{ P-value } & \multirow[t]{3}{*}{ OR (IC95\%) } \\
\hline & & \multicolumn{2}{|c|}{ Yes } & \multicolumn{2}{|l|}{ No } & \multicolumn{2}{|l|}{ Total } & & \\
\hline & & $\mathbf{N}$ & $\%$ & $\mathbf{N}$ & $\%$ & $\mathbf{N}$ & $\%$ & & \\
\hline \multirow[t]{2}{*}{ Head } & Yes & 22 & 6.0 & 71 & 5.1 & 93 & 5.3 & 0.527 & $1.17(0.72-1.92)$ \\
\hline & No & 346 & 94.0 & 1309 & 94.9 & 1655 & 94.7 & & 1.00 \\
\hline \multirow[t]{2}{*}{ Face } & Yes & 64 & 17.4 & 151 & 10.9 & 215 & 12.3 & 0.001 & $1.71(1.25-2.36)$ \\
\hline & No & 304 & 82.6 & 1229 & 89.1 & 1533 & 87.7 & & 1.00 \\
\hline \multirow[t]{2}{*}{ Thorax } & Yes & 32 & 8.7 & 268 & 19.4 & 300 & 17.2 & $<0.001$ & 1.00 \\
\hline & No & 336 & 91.3 & 1112 & 80.6 & 1448 & 82.8 & & $2.53(1.72-3.72)$ \\
\hline \multirow[t]{2}{*}{ Arms and hands } & Yes & 99 & 26.9 & 481 & 34.9 & 580 & 33.2 & 0.004 & 1.00 \\
\hline & No & 269 & 73.1 & 899 & 65.1 & 1168 & 66.8 & & $1.45(1.13-1.88)$ \\
\hline \multirow[t]{2}{*}{ Legs and feet } & Yes & 203 & 55.2 & 444 & 32.2 & 647 & 37.0 & $<0.001$ & $2.59(2.05-3.28)$ \\
\hline & No & 165 & 44.8 & 936 & 67.8 & 1101 & 63.0 & & 1.00 \\
\hline
\end{tabular}

Regarding the number of lesions, $40.4 \%$ of victims had multiple lesions and $69.7 \%$ required a single surgical intervention. The presence of fractures was observed in $80.6 \%$ of patients. There was an association between the occurrence of motorcycle accidents with the number of lesions ( $p$ $<0.001)$, number of surgical interventions $(p<0.001)$ and presence of fractures $(p<0.001)$. Victims of motorcycle accidents were 3.5 times more likely to have vascular lesions in the lower limbs and 7.8 times more likely to suffer bone fractures (Table 3 ).

The presence of functional impairment was observed in $15.3 \%$ of the victims, while the occurrence of amputation was $4.3 \%$. The number of deaths recorded was extremely low (1.3\%). There was association between the occurrence of motorcycle accidents and the existence of functional impairment $(p=0.002)$ and the presence of limb amputation $(p=0.010)$, so that victims of motorcycle accidents were 2.2 times more likely to suffer amputation (Table 4). 
Table 3: Number of lesions, presence of vascular lesion in the lower limbs, number of surgical interventions and presence of fractures associated with motorcycle accidents

\begin{tabular}{|c|c|c|c|c|c|c|c|c|}
\hline \multirow{3}{*}{ Variable } & \multicolumn{8}{|c|}{ Motorcycle accidents } \\
\hline & \multicolumn{2}{|c|}{ Yes } & \multicolumn{2}{|c|}{ No } & \multicolumn{2}{|c|}{ Total Group } & \multirow[t]{2}{*}{ P-value } & \multirow[t]{2}{*}{ OR (IC95\%) } \\
\hline & $\mathrm{N}$ & $\%$ & $\mathrm{n}$ & $\%$ & $\mathrm{n}$ & $\%$ & & \\
\hline \multicolumn{9}{|l|}{ No. of lesions } \\
\hline Single & 220 & 59.6 & 1006 & 71.4 & 1226 & 69.0 & $<0.001$ & 1.00 \\
\hline Multiple & 149 & 40.4 & 403 & 28.6 & 552 & 31.0 & & $1.69(1.33-2.14)$ \\
\hline \multicolumn{9}{|c|}{ Vascular lesion in the lower limbs } \\
\hline Yes & 8 & 57.1 & 18 & $27 \cdot 3$ & 26 & 32.5 & 0.056 & $3.56(1.08-11.68)$ \\
\hline No & 6 & 42.9 & 48 & 72.7 & 54 & 67.5 & & 1.00 \\
\hline \multicolumn{9}{|c|}{ No. of surgical interventions } \\
\hline No treatment & 76 & 20.5 & 454 & 32.3 & 530 & 29.9 & $<0.001$ & 1.00 \\
\hline One & 258 & 69.7 & 865 & 61.6 & 1123 & $63 \cdot 3$ & & $1.78(1.35-2.36)$ \\
\hline Two or more & 36 & 9.7 & 85 & 6.1 & 121 & 6.8 & & $2.53(1.60-4.00)$ \\
\hline \multicolumn{9}{|l|}{ Fractures } \\
\hline Yes & 300 & 80.6 & 491 & 34.7 & 791 & 44.2 & $<0.001$ & $7.86(5.94-10.39)$ \\
\hline No & 72 & 19.4 & 926 & $65 \cdot 3$ & 998 & 55.8 & & 1.00 \\
\hline
\end{tabular}

Table 4: Number (proportion) of functional impairment, limb amputation and death due to motorcycle accidents

\begin{tabular}{|c|c|c|c|c|c|c|c|c|}
\hline \multirow{3}{*}{ Variable } & \multicolumn{8}{|c|}{ Motorcycle accidents } \\
\hline & \multicolumn{2}{|c|}{ Yes } & \multicolumn{2}{|c|}{ No } & \multicolumn{2}{|c|}{ Total Group } & \multirow[t]{2}{*}{ p-value } & \multirow[t]{2}{*}{ OR (IC95\%) } \\
\hline & $\mathrm{n}$ & $\%$ & $\mathrm{n}$ & $\%$ & $\mathrm{n}$ & $\%$ & & \\
\hline \multicolumn{9}{|c|}{ Functional impairment } \\
\hline Yes & 57 & $15 \cdot 3$ & 137 & 9.7 & 194 & 10.8 & $p=0.002$ & $1.69(1.21-2.36)$ \\
\hline No & 315 & 84.7 & 1280 & 90.3 & 1595 & 89.2 & & 1.00 \\
\hline \multicolumn{9}{|c|}{ Limb amputation } \\
\hline Yes & 16 & $4 \cdot 3$ & 28 & 2.0 & 44 & 2.5 & $p=0.010$ & $2.23(1.19-4.17)$ \\
\hline No & 356 & 95.7 & 1389 & 98.0 & 1745 & 97.5 & & 1,00 \\
\hline \multicolumn{9}{|l|}{ Death } \\
\hline Yes & 5 & 1.3 & 22 & 1.6 & 27 & 1.5 & $p=0.769$ & 1.00 \\
\hline No & 367 & 98.7 & 1395 & 98.4 & 1762 & 98.5 & & $1.16(0.44-3.08)$ \\
\hline
\end{tabular}

\section{Discussion}

In recent years, injuries caused by traffic accidents have become one of the main causes of death and disability worldwide (Peden et al., 2004; WHO, 2009). Several countries (Clarke et al., 2007; Savolainen \& Mannering, 2007; Albalate \& Fernàndez-Villadangos, 2010), including Brazil (Reichenheim et al., 2011), have experienced a considerable increase in the number of accidents involving motorcycles in response to the significant growth in the number of these vehicles. Despite its widespread use, the significant number of motorcycle accidents shows the vulnerability of motorcyclists due to the lower stability of motorcycles compared to other vehicles (Mallikarjuna \& Krishnappa, 2009) and greater body exposure of the motorcyclists (Jain et al., 2009; Albalate \& Fernàndez-Villadangos, 2010; Saadat \& Soori, 2011). In association with the previously mentioned factors, it is important to emphasize that traffic disorganization, failure in vehicle inspection, poor maintenance conditions, reckless driving and the impunity of infringers, significantly contribute to the occurrence of traffic accidents, especially involving motorcyclists (Bastos et al., 2005; Reichenheim et al., 2011). 
Analyzing the profile of motorcyclists in this study, a predominance of male victims was observed. Similar to findings have been reported by other studies (Fitzharris et al., 2009; Jain et al., 2009; Nunn, 2011; Talving et al., 2010; Weiss et al., 2010). In terms of age, individuals in the third decade were among the most affected, which corroborates other findings (Mallikarjuna \& Krishnappa, 2009; Weiss et al., 2010; Hashim \& Iqbal, 2011). Thus, it is important to emphasize that the greater involvement of young male individuals in motorcycle accidents is mainly the result of the reckless driving of such vehicles (Bacchieri \& Barros, 2011; Saadat \& Soori, 2011).

More than one third of accidents observed in this study occurred over the weekend, similar to results found in studies in Australia (Jamaa et al., 2011), New Zeeland (Jamaa et al., 2011), United States (Nunn, 2011) and India (Mallikarjuna \& Krishnappa, 2009). Santos et al. (2008) have observed that there is three times greater chance of accidents over the weekend among motorcyclists who had used alcohol. In this sense, although the high number of accidents occurred on weekends is suggestive for association with alcohol consumption, this study did not obtain data about the alcohol consumption of motorcyclists. Alcohol consumption among Brazilian drivers involved in traffic accidents is considered very common (Bacchieri \& Barros, 2011; Reichenheim et al., 2011).

This study identified that the body part most frequently injured were the upper and lower limbs, similar to results reported by others (Gawryszewski et al., 2003; Sirathranont \& Kasantikul, 2003; Talving et al., 2010). Consistent with this study, cases of limb amputations associated with motorcycle accidents were also reported by other authors (Obalum \& Okeke, 2009; Talving et al., 2010). Another important aspect related to limb injuries found in this study relates to vascular lesions in the lower limbs. Cases of vascular lesions in the lower limbs are also associated with significant rates of limb loss and functional impairment (Bechara \& Huynh, 2007). In this context, it is noteworthy that although not considered vital regions, lesions in body extremities can result in long morbidity periods (Kraus et al., 2002).

Although this study found no statistically significant difference between the occurrence of head injuries and motorcycle accident, several studies have shown that the head is one of the body parts most injured in accidents involving motorcycles (Kraus et al., 2002; Oluwadiyaa et al., 2009; Fitzharris et al., 2009), especially among drivers and passengers not using helmets (Soumitra et al., 1995; Fitzharris et al., 2009; Crompton et al., 2011). The use of helmets has been reported to reduce the mortality rate from 37\%-40\% (Mikocka-Walus et al., 2010; Crompton et al., 2011 ) of cases of motorcycle accidents, and reduce by $65 \%$ the possibility of traumatic brain injury (Crompton et al., 2011). Therefore, the use of helmet is important, since head injury is a cause commonly associated with death and long-term disability (MacLeod et al., 2010). Although in this study, thorax injuries were few, other studies have shown that this region can be frequently affected by motorcycle accidents (Soumitra et al., 1995; Kraus et al., 2002; Mikocka-Walus et al., 2010; Talving et al., 2010).

The number of fatally injured motorcyclists found in this study was proportionally low. However, the high proportion of bone fractures showed by the majority of motorcyclists involved in accidents attracts attention, demonstrating that they are eight times more likely to be injured in case of accidents. Consistent with these findings, the presence of fractures in different body parts has been reported in other studies (Sirathranont \& Kasantikul, 2003; Crandon et al., 2009; Oluwadiyaa et al., 2009; Talving et al., 2010). Due to the bone involvement, victims of fractures require longer hospital stays, as they need intervention procedures that require longer follow-up and recovery time (Amin et al., 2011).

One of the limitations of this study is the source of data. One of the difficulties in working with secondary data lies in the fact that in many situations, the incomplete recording of information prevents the transcription of findings. In this study, some medical records were not properly filled, preventing the acquisition of some information of interest.

In conclusion, accidents involving motorcycles predominantly affect young men, causing multiple fractures and injuries, especially in the lower limbs. The cases of limb amputation and 
functional impairment involving motorcyclists show the severity of accidents associated with this type of road transportation.

\section{References}

Albalate D, Fernàndez-Villadangos L. (2010) Motorcycle injury severity in Barcelona: The role of vehicle type and congestion. Traffic Injury Prevention 11(6):623-631.

Amin NH, Jakoi A, Katsman A, Harding SP, Tom JA, Cerynik DL. (2011) Incidence of orthopedic surgery intervention in a level I urban trauma center with motorcycle trauma. Journal of Trauma 71(4):948-951.

Bacchieri G, Barros AJD. (2011) Acidentes de trânsito no Brasil de 1998 a 2010: muitas mudanças e poucos resultados. Revista de Saúde Pública 45(5):949-963.

Bastos YGL, Andrade SM, Soares DA. (2005) Características dos acidentes de trânsito e das vítimas atendidas em serviço pré-hospitalar em cidade do Sul do Brasil, 1997/2000. Cadernos de Saúde Pública 21(3):815-822.

Bechara C, Huynh TT, Lin PH. (2007) Management of lower extremity arterial injuries. The Journal of Cardiovascular Surgery 48(5):567-579.

Bevan AC, Babl FE, Bolt P, Sharwood LS. (2008) The increasing problem of motorcycle injuries in children and adolescents. Medical Journal of Australia 189(1):17-20.

Cavalcanti AL, Monteiro BV, Oliveira TBS, Ribeiro RA, Monteiro BSB. (2011) Mortality due to traffic accidents and occurrence of maxillofacial fractures. Revista Brasileira de Odontologia 68(2):220-224.

Clarke DD, Ward P, Bartle C, Truman W. (2007) The role of motorcyclist and other driver behavior in two types of serious accident in the UK. Accident Analysis \& Prevention 39(5):974-981.

Coben JH, Steiner CA, Owens P. (2004) Motorcycle-related hospitalizations in the United States, 2001. American Journal of Preventive Medicine 27(5):355-362.

Crandon IW, Harding HE, Cawich SO, McDonald AH, Fearron-Boothe D. (2009) Motorcycle accident injury profiles in Jamaica: an audit from the University Hospital of the West Indies. International Journal of Injury Control and Safety Promotion 16(3):175-178.

Crompton JG, Bone C, Oyetunji T, Pollack KM, Bolorunduro O, Villegas C, Stevens K, Cornwell EE 3rd, Efron DT, Haut ER, Haider AH. (2011) Motorcycle helmets associated with lower risk of cervical spine injury: debunking the myth. Journal of the American College of Surgeons 212(3):295-300.

Fitzharris M, Dandona R, Kumar G A, Dandona L. (2009) Crash characteristics and patterns of injury among hospitalized motorised two-wheeled vehicle users in urban India. BMC Public Health 9:1-11.

Gawryszewski VP, Coelho HMM, Scarpelini S, Zan R, Jorge MHPM, Rodrigues SEM. (2009) Perfil dos atendimentos a acidentes de transporte terrestre por serviços de emergência em São Paulo, 2005. Revista de Saúde Pública 43(2):275-282.

Germeni E, Lionis C, Davou B, Petridou ET. (2009) Understanding reasons for non-compliance in motorcycle helmet use among adolescents in Greece. Injury Prevention 15(1):19-23.

Haquea M, Chinb HC, Huanga H. (2009) Modeling fault among motorcyclists involved in crashes. Accident Analysis \& Prevention 41(2):327-335.

Hashim H, Iqbal S. (2011) Motorcycle accident is the main cause of maxillofacial injuries in the Penang Mainland, Malaysia. Dental Traumatology 27(1):19-22.

Jain A, Menezes RG, Kanchan T, Gagan S, Jain R. (2009) Two wheeler accidents on Indian roads a study from Mangalore, India. Journal of Forensic and Legal Medicine 16(3):130-133.

Jamaa HH, Grzebietaa RH, Friswella R, McIntoshb AS. (2011) Characteristics of fatal motorcycle crashes into roadside safety barriers in Australia and New Zealand. Accident Analysis \& Prevention 43(3): 652-660.

Kraus J F, Peek-Asa C, Cryer HG. (2002) Incidence, severity, and patterns of intrathoracic and intraabdominal injuries in motorcycle crashes. Journal of Trauma 52(3):548-553. 
Lin M, Chang S, Huang W, Hwang H, Pai L. (2003) Factors associated with severity of motorcycle injuries among young adult riders. Annals of Emergency Medicine 41(6):783-791.

MacLeod JBA, DiGiacomo JC, Tinkoff G. (2010) An evidence-based review: Helmet efficacy to reduce head injury and mortality in motorcycle crashes: EAST practice management guidelines. Journal of Trauma 69(5):1101-1111.

Mallikarjuna S K, Krishnappa P. (2009) Prevalence of maxillofacial injuries by motorized two wheeler road traffic accidents in Bangalore city. Dental Traumatology 25(6):599-604.

Mikocka-Walus A, Gabbe B, Cameron P. (2010) Motorcycle-related major trauma: On-road versus off-road incidence and profile of cases. Emergency Medicine Australasia 22(5):470-476.

Naci, H., Chisholm D, Baker TD. (2009) Distribution of road traffic deaths by road user group: a global comparison. Injury Prevention 15(1):55-59.

Nunn S. (2011) Death by motorcycle: background, behavioral, and situational correlates of fatal motorcycle collisions. Journal of Forensic Sciences 56 (2):429-437.

Obalum DC, Okeke GC. (2009) Lower limb amputations at a Nigerian private tertiary hospital. West African Journal of Medicine 28(1):24-27.

Oluwadiyaa KS, Kolawoleb IK, Adegbehingbed OO, Olasindee AA, Agodirina O, Uwaezuokec SC. (2009) Motorcycle crash characteristics in Nigeria: Implication for control. Accident Analysis \& Prevention 41(2):294-298.

Peden M, Scurfield R, Sleet D, Mohan D, Hyder AA, Jarawan E. (2004) World report on road traffic injury prevention. Geneva: World Health Organization.

Reichenheim ME, Souza ER, Moraes CL, Mello Jorge MHP, Silva CMFP, Minayo MCS. (2011) Violence and injuries in Brazil: the effect, progress made, and challenges ahead. Lancet 377(9781):1962-1975.

Saadat S, Soori H. (2011) Epidemiology of traffic injuries and motor vehicles utilization in the Capital of Iran: A population based study. BMC Public Health 11:488.

Santos AMR, Moura MEB, Nunes BMVT, Leal CFS, Teles JBM. (2008) Perfil das vítimas de trauma por acidente de moto atendidas em um serviço público de emergência. Cadernos de Saúde Pública 24(8):1927-1938.

Savolainen P, Mannering F. (2007) Probabilistic models of motorcyclists' injury severities in singleand multi-vehicle crashes. Accident Analysis \& Prevention 39(5): 955-963.

Sirathranont J, Kasantikul V. (2003) Mortality and injury from motorcycle collisions in Phetchaburi Province. Journal of the Medical Association of Thailand 86, 97-102.

Soumitra S, Corinne P, Jess FK. (1995) Fatal injuries in motorcycle riders according to helmet use. Journal of Trauma 38, 242-245.

Talving P, Teixeira PG, Barmparas G, Dubose J, Preston C, Inaba K, Demetriades D. (2010) Motorcycle-related injuries: Effect of age on type and severity of injuries and mortality. Journal of Trauma 68, 441-446.

Weiss H, Agimi Y, Steiner C. (2010) Youth motorcycle-related hospitalizations and traumatic brain injuries in the United States in 2006. Pediatrics 126(6):1141-1148.

WHO (2009) Global status report on road safety: time for action. Geneva: World Health Organization. 